\title{
Evaluating growth and age of netted whelk Nassarius reticulatus (Gastropoda: Nassariidae) using statolith growth rings
}

\author{
E. Chatzinikolaou, C. A. Richardson* \\ School of Ocean Sciences, University of Wales Bangor, Menai Bridge, Anglesey LL59 5AB, UK
}

\begin{abstract}
The periodicity of growth rings in the statoliths of Nassarius reticulatus (Linnaeus, 1758) was validated using laboratory-reared larvae and juveniles of known age. Formation of the first ring occurred at larval settlement and subsequent rings were deposited annually. Wider light increments formed between March and June when seawater temperatures increased from 10.9 to $19.4^{\circ} \mathrm{C}$, whereas darker narrow rings formed between the late summer and winter. Counts of the annual statolith rings were used to determine the age of $N$. reticulatus collected from six locations around the Anglesey coast, North Wales. The oldest whelks, 7 and 6 yr respectively, occurred in a sheltered lagoon at Rhosneigr and from a sheltered area between Cemlyn Bay and Carmel Head. Lack of geographical variations in settlement ring size suggests that the larvae spend a similar period of time in the plankton before settlement. Significant differences in the diameters of the annual rings indicate that wave exposure and food availability may affect growth at different locations. The relationship between statolith diameter (SDi) and shell length (ShL) for larvae, juvenile and adult $N$. reticulatus $(0.3$ to $31 \mathrm{~mm})$ was SDi $(\mu \mathrm{m})=36.31 \times \operatorname{ShL}(\mathrm{mm})^{0.464}$. No statistically significant differences in this relationship were found amongst the 6 Anglesey locations or between whelks of different gender. Using the equation, ShL at formation of each annual ring was estimated, and von Bertalanffy growth (VBG) curves fitted to the length-age data. Whelks from the sheltered Rhosneigr lagoon had the highest asymptotic maximum ShL $\left(\mathrm{L}_{\infty}\right)$ and the lowest growth constant $(K)$, suggesting a slow growth over a period of time. Growth rates of males, females and imposex-affected females were similar.
\end{abstract}

KEY WORDS: Nassarius reticulatus $\cdot$ Statoliths $\cdot$ Age $\cdot$ Growth $\cdot$ Gastropods

Resale or republication not permitted without written consent of the publisher

\section{INTRODUCTION}

Early attempts at determining the age of gastropods have relied mainly on shell size, shell lip thickness and enumeration of teeth on the inner aperture lip margin e.g. Nucella lapillus (Coombs 1973) and Strombus gigas (Appeldoorn 1988). The use of shell lip thickness for estimating the age of gastropods has been problematic because of erosion of the edge of the shell lip with time (Stoner \& Sandt 1992). The external shell surface of some archaeogastropods reveals distinctive annual growth marks and these have been used for studying growth patterns and for determining the age of Monodonta lineata (Williamson \& Kendall 1981) and Fissu- rella crassa (Bretos 1980). For most species, however, the outer shell surface has few shell marks or rings that can be used reliably for age estimation (Richardson 2001). The age of the netted whelk Nassarius reticulatus has been determined from external shell rings by Tallmark (1980) (up to 15 rings) and Barroso et al. (2005a) (up to 6 rings) although both these studies found that the rings became less discernible as the gastropods increased in size, suggesting that age estimates based on external ring counts may be underestimated. The gastropod shell margin is frequently damaged and repaired, resulting in the production of growth checks, which can be difficult to distinguish from those of annual origin (Richardson et al. 2005b). 
Sections of abalone shells reveal internal growth lines which form during periods of maximum and minimum seawater temperatures and during the spawning season (Shepherd et al. 1995). Tidally deposited growth bands are formed in the shells of the limpet Patella vulgata during emersion at low tide (Ekaratne \& Crisp 1984). The reconstruction of a continuous sequence of growth from the conical spired shells of mesogastropods and neogastropods is complicated without serial sectioning (Richardson 2001), hence only a few studies have studied shell margin sections e.g. P. vulgata (Ekaratne \& Crisp 1984) and N. reticulatus (Barroso et al. 2005a).

A recent development in gastropod ageing studies is the identification of statolith growth rings (Barroso et al. 2005b, Richardson et al. 2005a,b). Statoliths are found in statocysts, the sense organs for equilibration, which provide the animal with information on the direction of gravity with reference to the animal's position (Dorsett 1986). Squid statoliths are structures similar to fish otoliths, that are formed of aragonite deposited on a protein matrix and which exhibit periodic growth increments (Radtke 1983). The daily increments identified in squid statoliths have provided information on the age (number of daily increments), growth rate (width of increments) and change of habitat through ontogeny (Arkhipkin \& Bizikov 1997). Over the last $25 \mathrm{yr}$ statoliths have been used to determine the age of many cephalopod species (Jackson 2004).

Statolith growth rings have been used to deter- 53⒉ mine the age of gastropod larvae (Bell 1984, Grana-Raffucci \& Appeldoorn 1997, Zacherl et al. 2003) and adults (Barroso et al. 2005b, Richardson et al. 2005a,b). Bell (1984) observed that the number of statolith increments corresponded with the age in days after hatching in Littorina scabra larvae. Recently statoliths of Concholepas concholepas larvae have been used as natural tags of natal origin for discrimination between larvae from geographically separated sites (Zacherl et al. 2003). Statolith rings could thus be useful tools for understanding aspects of the life history and ecology of gastropods (Grana-Raffucci \& Appeldoorn 1997) providing the periodicity of the rings has been validated. Statolith rings have been used to estimate the age of Polinices pulchellus (Richardson et al. 2005a), Neptunea antiqua (Richardson et al. 2005b) and Nassarius reticulatus (Barroso et al. 2005b). The first statolith ring has been related to the hatching of $C$. concholepas larvae (Zacherl et al. 2003) and to larval settlement in P. pulchellus (Richardson et al. 2005a) and in N. reticulatus (Barroso et al. 2005b), whilst the prominent rings are thought to be deposited annually in P. pulchellus (Richardson et al. 2005a) and N. reticulatus (Barroso et al. 2005b).

The present paper reports detailed laboratory and field experiments to ascertain the periodicity of ring formation in the statoliths of larval, juvenile and adult Nassarius reticulatus and to validate their use as a tool for estimating the age of this gastropod. The rings were used to investigate the shell growth of $N$. reticulatus collected at 6 different locations from the coastal waters of Anglesey, North Wales.

\section{MATERIALS AND METHODS}

Nassarius reticulatus were collected from 6 locations around Anglesey, North Wales (Fig. 1) using a line of 5 to 10 traps, (depending on the location), baited with mackerel and deployed for a period of $30 \mathrm{~min}$. Forty $N$. reticulatus were collected from an intertidal lagoon at Rhosneigr during June 2003 (length 8.3 to $27.9 \mathrm{~mm}$ ), 40 in August 2003 (9.9 to $30.8 \mathrm{~mm}$ ), 40 in November 2003 (6.4 to $30.0 \mathrm{~mm}$ ) and 40 in February 2004 (8.2 to $29.6 \mathrm{~mm}$ ). A further $40 \mathrm{~N}$. reticulatus were collected in July 2003 from Rhosneigr beach (15.6 to $27.8 \mathrm{~mm}$ ), 40 from Malltraeth beach (12.3 to $31.4 \mathrm{~mm}$ ), 40 from Church Bay (11.4 to $21.1 \mathrm{~mm}), 39$ from the shores be-

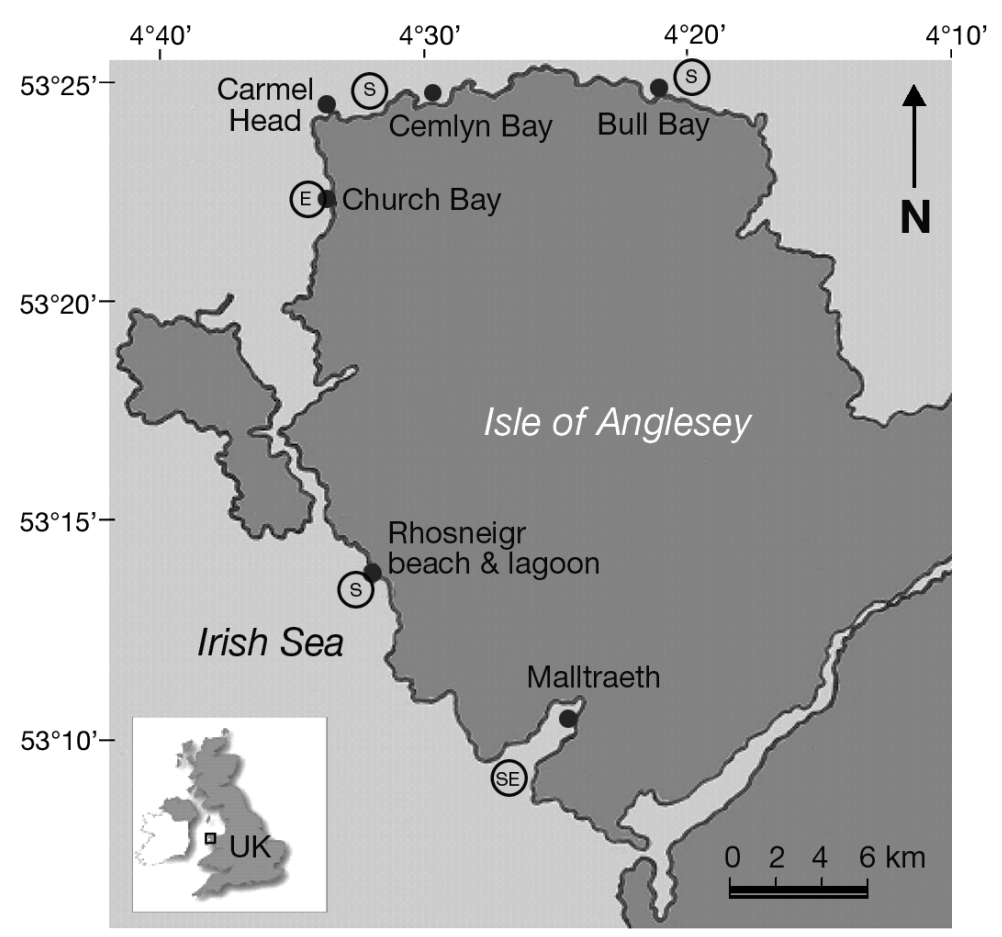

Fig. 1. Location of sampling sites around Anglesey (North Wales, UK) and shore classification according to Ballantine's (1961) biologically-defined exposure scale (S: sheltered; E: exposed; SE: semi-exposed) 
tween Carmel Head and Cemlyn Bay (14.6 to $26.2 \mathrm{~mm})$ and 13 from Bull Bay (15.4 to $26.2 \mathrm{~mm}$ ) (Fig. 1). All whelks were frozen until required.

Upon thawing, shell length (ShL; spire to the edge of the siphonal canal), and shell lip thickness were measured to the nearest $0.1 \mathrm{~mm}$ using vernier callipers. The thickness (condition) of the shell lips was categorised as Stage 1 (CL1, thin sharp shell lips), Stage 2 (CL2, thickened lips), Stage 3 (CL3, thick lips and a row of single teeth) and Stage 4 (CL4, thick lips and a wide row of elongated teeth) (modified for Nassarius reticulatus from Crothers (1985) description of Nucella lapillus). The shell was crushed with a bench vice and the attachment between the columellar muscle and the shell severed. The gender and possible imposex stage (superimposition of male characters onto females) of each $N$. reticulatus were identified using Stroben et al.'s (1992) description. The viscera and operculum were discarded and the animal immersed dorsal side up in a glass petri dish $(50 \mathrm{ml})$ containing $1 \mathrm{M} \mathrm{NaOH}$ solution until the flesh was fully digested (up to $12 \mathrm{~h}$ ), enabling the statoliths to be extracted.

The 2 statoliths within their statocysts, which are located in the foot tissue between the cerebropleural and pedal ganglia, were removed under a dissecting microscope and transferred using a Pasteur pipette to a watch glass, rinsed with deionised water (2 min) and then $70 \%$ alcohol (5 min) and left to air-dry (5 min). Each statolith of a pair was transferred onto a microscopic slide, immersed in warmed CrystalBond ${ }^{\mathrm{TM}} 509$ resin and orientated with its long axis flat. Each statolith was photographed using a digital camera (Color View, Soft Imaging System) attached to a microscope and the statolith images interpreted with the software package AnalySIS (Version 3.2, Soft Imaging System). The number of rings in each statolith was counted and the nucleus diameter, statolith diameter (SDi) and the distance between the rings were measured. The term 'ring' in the present study refers to the dark segment of the bipartite structure (a dark and a light ring together) that constitutes an increment.

Statoliths were extracted from embryos, larvae and juveniles of Nassarius reticulatus that had been reared in the laboratory. Egg capsules laid by spawning adult $N$. reticulatus held in laboratory aquaria were transferred to a 21 glass beaker containing 1.81 of continuously aerated $0.2 \mu \mathrm{m}$-filtered, ultra violet-irradiated seawater at ambient temperature $\left(15\right.$ to $\left.18^{\circ} \mathrm{C}\right)$ and left to hatch. Prior to hatching, 20 embryos were removed from the egg capsules and their statoliths measured. On the day following hatching the larvae were collected with a $63 \mu \mathrm{m}$ plankton sieve and back-washed off the sieve into a beaker containing $1700 \mathrm{ml}$ of $0.2 \mu \mathrm{m}$ filtered ultra violet-irradiated seawater. Every $3 \mathrm{~d}$ the seawater was changed and the larvae provided with
0.11 of an algal culture containing equal volumes of monocultures of Rhinomonas reticulatus (900 cells $\left.\mu^{-1}\right)$, Pavlova lutheri (3500 cells $\mu^{-1}$ ), Tetraselmis chui (100 cells $\mu^{-1}$ ) and Skeletonema costatum (2000 cells $\mu^{-1}$ ). Sub-samples of 20 larvae were removed at weekly intervals between hatching and settlement for examination of the larval statoliths. When the larvae approached metamorphosis crawling individuals were transferred into a small plastic tank (length, height, depth $=17 \times 10 \times 11 \mathrm{~cm}$ ) containing a 5 to $10 \mathrm{~mm}$ layer of fine sand and supplied with running seawater at ambient temperature. The newly metamorphosed juveniles were fed with small pieces of mackerel or mussel flesh several times a week and were successfully reared for up to $500 \mathrm{~d}$. Sub-samples of these juveniles (the number depending on availability) were taken at roughly monthly intervals for observation of the juvenile statoliths. The ShL of the embryos, larvae and juveniles was measured under a microscope to the nearest $0.01 \mathrm{~mm}$ using a calibrated eyepiece graticule. Following measurement they were placed in a cavity slide with a few drops of $1 \mathrm{M} \mathrm{NaOH}$ solution and the shell crushed by applying gentle pressure with tweezers. Shell fragments were removed and further digestion ( 4 to $5 \mathrm{~h}$ ) was completed in the $\mathrm{NaOH}$. The statoliths were isolated, rinsed and mounted in resin as described above.

The statoliths of whelks collected from Rhosneigr lagoon in June, August, and November 2003 and in February 2004 were used to establish in which season the statolith growth rings were deposited and to investigate whether there was a seasonal variation in the relationship between ShL and SDi. Using statoliths from the 4 seasonal samples the distance between the last formed dark ring and the circumference of the statolith, which represents the developing, lighter wider growth increment at a particular time, was measured in the 5th ring in order to reduce variations in increment size due to differences in growth rates amongst individuals of different age and size. The statoliths of whelks from the 6 Anglesey locations were compared to investigate potential regional differences in the statolith growth patterns. An equation between SDi and ShL was established using data from statolith measurements obtained from larvae, juvenile and adult Nassarius reticulatus, and the equation was then used to estimate whelk ShL at the formation of each statolith ring. Von Bertalanffy growth (VBG) curves were fitted to the derived lengthat-age data using the equation $\mathrm{L}(t)=\mathrm{L}_{\infty}\left(1-\mathrm{e}^{-K\left(t-t_{0}\right)}\right)$, where $\mathrm{L}_{\infty}$ is the asymptotic maximum $\mathrm{ShL}, K$ is the growth constant and $t_{0}$ is the theoretical age at which ShL would have been zero (FISAT II, Version 1.2.0). Differences between the VBG curves were examined by comparing the VBG parameters $\mathrm{L}_{\infty}, K$ and $t_{0}$ of each group (i.e. different sexes, different sampling areas) in 
pairs using Hotelling's $\mathrm{T}^{2}$ test, modified to an $F$ statistic (see Bernard 1981). The critical value of $\mathrm{T}_{0}{ }^{2}$, which is a modified tabulated $F$ statistic, is used to test the estimated $\mathrm{T}^{2}$ statistic for significance $(a=0.001)$. When $\mathrm{T}^{2}>$ $\mathrm{T}_{0}{ }^{2}$, growth between a pair of groups is described as dissimilar, and when $\mathrm{T}^{2}<\mathrm{T}_{0}{ }^{2}$, growth is similar. When Hotelling's $\mathrm{T}^{2}$ test was found to be statistically significant $\left(\mathrm{T}^{2}>\mathrm{T}_{0}{ }^{2}\right)$ the Roy-Bose simultaneous confidence intervals around differences between the parameters were estimated in order to indicate which of the three parameters contributed most to the statistical significance. When the confidence intervals did not include zero the parameters had a statistically significant influence on the differences in growth between the 2 comparisons.

Validation of the periodicity in the statolith rings and an assessment of annual changes in shell growth were undertaken using statoliths from marked individuals whose initial and final shell sizes were measured and whose shell growth in the field was monitored op- portunistically over a period of $\sim 2$ yr. We collected 566 Nassarius reticulatus (initial ShL 7.9 to $31.4 \mathrm{~mm}$ ) from the Rhosneigr lagoon in June 2002, labelled them individually with a numbered tag, and measured their length before release (within $24 \mathrm{~h}$ ) back into the lagoon. The whelks were re-captured opportunistically during monthly collections and their length remeasured; 21 of the marked $N$. reticulatus that were re-captured between August and September 2004, 26 to 27 mo after marking and release, were sacrificed and their statoliths extracted.

\section{RESULTS}

\section{Formation and periodicity of statolith growth rings}

In newly hatched Nassarius reticulatus larvae the pair of statoliths and their position in the foot tissue were visible directly through the thin larval shell for
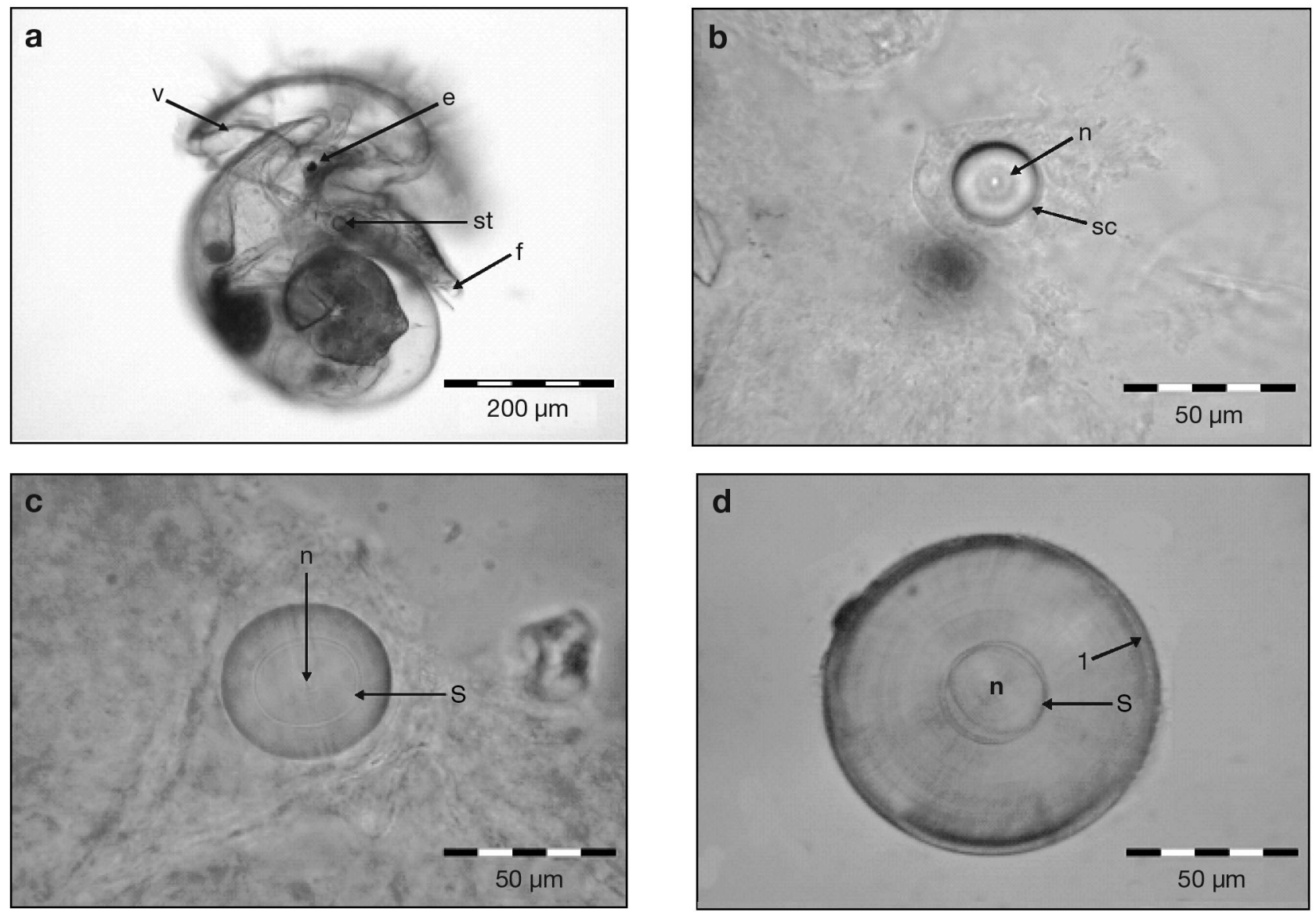

Fig. 2. Nassarius reticulatus. Statoliths from larvae and juveniles. (a) Statolith in 4 d old larva clearly visible through shell: v: velum; e: eye; st: statolith; f: foot; (b) statocyst containing statolith in 2 wk old larva where no ring has yet formed (n: nucleus; sc: statocyst); (c) statolith of $132 \mathrm{~d}$ old juvenile (94 d after settlement) in which nucleus and settlement ring (S) are visible; (d) statolith of $500 \mathrm{~d}$ old juvenile (469 d after settlement) where (S) and first annual (1) rings can be seen. Due to orientation of this statolith in the resin a double settlement ring can be seen 


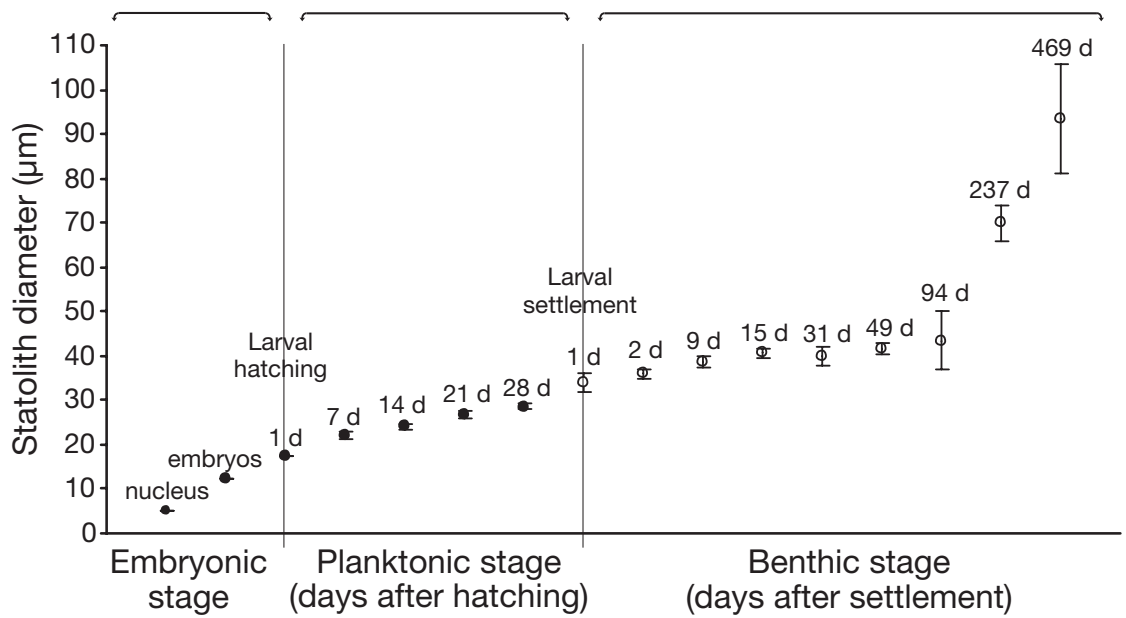

Fig. 3. Nassarius reticulatus. Temporal increase in mean SDi $( \pm 95 \%$ CI) of larvae during $(\bullet)$ embryonic and planktonic stages and (०) juvenile benthic stage. Days after hatching and settlement indicated above symbols. Nucleus diameters and SDis of embryos and newly hatched larvae were identical in all individuals examined, i.e. $95 \%$ CI not applicable

up to 5 wk after hatching (Fig. 2a) thus enabling their direct measurement. The statoliths are semi-transparent and 3-dimensional with an elliptical shape, and in older whelks they could only be observed after removal. The pattern of statolith rings in larvae and juveniles of known age was used to ascertain at what stage in the whelk's life the nucleus, settlement and first rings were deposited (Fig. 2). In embryos, larvae and juveniles of different age the statolith nucleus diameter (n) measured exactly $5 \mu \mathrm{m}$, indicating that the nucleus forms during early embryonic development. SDi prior to hatching measured exactly $12.5 \mu \mathrm{m}$, increasing in size rapidly following hatching to exactly
$17.5 \mu \mathrm{m}$ and, $1 \mathrm{~d}$ after settlement to 34.0 $\pm 1.15 \mu \mathrm{m}$ (Fig. 3). The SDi of $1 \mathrm{~d}$ settled larvae was not statistically significantly different (2-sample $t$-test: $t=0.73, \mathrm{p}=$ $0.467)$ from the diameter (33.19 \pm $0.13 \mu \mathrm{m}$, Table 1) of the $\mathrm{S}$ ring in adult whelks from the various locations. Similarly the settlement (S) ring diameter $(31.4 \pm 0.9 \mu \mathrm{m})$ in juveniles was not statistically significantly different (2-sample $t$-test: $t=1.38, \mathrm{p}=0.168$ ) from the $\mathrm{S}$ ring diameter $(33.19 \pm 0.13 \mu \mathrm{m})$ in the adult statolith. Taken together these findings clearly indicate that the first ring in juvenile and adult statoliths (Fig. 2 \& 4) forms at larval settlement, rather than at hatching. No rings were formed in the larval statolith before settlement (Fig. 2b), whereas in newly settled larvae a prominent first ring could be clearly seen (Fig. 2c-d).

Adult whelk (6.4 to $31.4 \mathrm{~mm}$ ) statoliths contained a clear pattern of 2 to 7 concentric rings (Fig. 4) with a first post-settlement ring diameter of $82.7 \pm 0.6 \mu \mathrm{m}$ (Table 1). The SDi of laboratory-reared whelks $<1 \mathrm{yr}$ old $(70.0 \pm 2.0 \mu \mathrm{m})$ (Fig. 3, $237 \mathrm{~d}$ after settlement) was statistically significantly smaller than the SDi of whelks $>1$ yr old $(93.6 \pm 6.1 \mu \mathrm{m}$ ) (Fig. 3, $469 \mathrm{~d}$ after settlement) and smaller than the diameter of the first postsettlement ring in the adult statolith $(82.7 \pm 0.6 \mu \mathrm{m})$ (ANOVA: $F=3.39, \mathrm{p}=0.035$ ). The first statolith annual ring of a laboratory-reared juvenile $>1 \mathrm{yr}$ old has a diameter of $95.5 \mu \mathrm{m}$ (Fig. 2d). No statistically significant difference (2-sample $t$-test: $t=1.69, \mathrm{p}=0.092)$ was

Table 1. Nassarius reticulatus. Mean diameter of settlement (S) ring and annual (1 to 7) rings in statoliths and estimated mean ShLs of whelks from 6 locations around Anglesey. Mean values for whelks from all areas are also presented. n.a. not applicable (only 1 measurement made). ${ }^{*}$ Statistically significant differences between areas

\begin{tabular}{|c|c|c|c|c|c|c|c|c|c|c|c|c|c|c|c|c|}
\hline \multirow[t]{2}{*}{ Location } & \multicolumn{8}{|c|}{ - Statolith ring diameters $(\mu \mathrm{m} \pm \mathrm{SE})-$} & \multicolumn{8}{|c|}{ Mean ShL estimated from statolith rings $(\mathrm{mm} \pm \mathrm{SE})$} \\
\hline & $\mathrm{S}$ & 1 & 2 & 3 & 4 & 5 & 6 & 7 & $\mathrm{~S}$ & 1 & 2 & 3 & 4 & 5 & 6 & 7 \\
\hline $\begin{array}{l}\text { Rhosneigr } \\
\text { lagoon }\end{array}$ & $\begin{array}{l}33.24 \\
(0.21)\end{array}$ & $\begin{array}{l}82.51 \\
(0.70)\end{array}$ & $\begin{array}{l}109.53 \\
(0.68)\end{array}$ & $\begin{array}{l}124.27 \\
(0.89)\end{array}$ & $\begin{array}{c}137.04 \\
(1.16)\end{array}$ & $\begin{array}{c}147.09 \\
(1.54)\end{array}$ & $\begin{array}{l}152.3 \\
(2.47)\end{array}$ & $\begin{array}{c}159.48 \\
(4.84)\end{array}$ & $\begin{array}{c}0.8 \\
(0.01)\end{array}$ & $\begin{array}{c}5.93 \\
(0.12)\end{array}$ & $\begin{array}{c}10.9 \\
(0.14)\end{array}$ & $\begin{array}{c}14.3 \\
(0.22)\end{array}$ & $\begin{array}{c}17.6 \\
(0.32)\end{array}$ & $\begin{array}{c}20.6 \\
(0.46)\end{array}$ & $\begin{array}{c}22.2 \\
(0.78)\end{array}$ & $\begin{array}{c}24.5 \\
(1.52)\end{array}$ \\
\hline Malltraeth & $\begin{array}{l}33.01 \\
(0.47)\end{array}$ & $\begin{array}{l}75.83 \\
(1.31)\end{array}$ & $\begin{array}{c}116.71 \\
(1.27)\end{array}$ & $\begin{array}{c}137.85 \\
(1.78)\end{array}$ & $\begin{array}{c}145.88 \\
(1.82)\end{array}$ & $\begin{array}{c}152.81 \\
(4.16)\end{array}$ & & & $\begin{array}{c}0.8 \\
(0.02)\end{array}$ & $\begin{array}{c}5.0 \\
(0.19)\end{array}$ & $\begin{array}{c}12.5 \\
(0.29)\end{array}$ & $\begin{array}{c}17.9 \\
(0.50)\end{array}$ & $\begin{array}{c}20.2 \\
(0.54)\end{array}$ & $\begin{array}{c}22.2 \\
(1.26)\end{array}$ & & \\
\hline $\begin{array}{l}\text { Rhosneigr } \\
\text { beach }\end{array}$ & $\begin{array}{l}33.26 \\
(0.33)\end{array}$ & $\begin{array}{l}87.24 \\
(1.59)\end{array}$ & $\begin{array}{l}118.57 \\
(1.28)\end{array}$ & $\begin{array}{l}135.37 \\
(1.47)\end{array}$ & $\begin{array}{c}146.06 \\
(1.60)\end{array}$ & $\begin{array}{c}153.25 \\
(3.10)\end{array}$ & & & $\begin{array}{c}0.8 \\
(0.02)\end{array}$ & $\begin{array}{c}6.7 \\
(0.27)\end{array}$ & $\begin{array}{c}13.0 \\
(0.32)\end{array}$ & $\begin{array}{c}17.2 \\
(0.43)\end{array}$ & $\begin{array}{c}20.2 \\
(0.50)\end{array}$ & $\begin{array}{c}22.4 \\
(0.98)\end{array}$ & & \\
\hline Bull Bay & $\begin{array}{l}33.00 \\
(0.30)\end{array}$ & $\begin{array}{l}83.55 \\
(3.57)\end{array}$ & $\begin{array}{l}121.34 \\
(2.82)\end{array}$ & $\begin{array}{c}141.21 \\
(2.54)\end{array}$ & $\begin{array}{c}148.32 \\
(4.46)\end{array}$ & & & & $\begin{array}{c}0.8 \\
(0.02)\end{array}$ & $\begin{array}{c}6.2 \\
(0.63)\end{array}$ & $\begin{array}{c}13.6 \\
(0.67)\end{array}$ & $\begin{array}{c}18.8 \\
(0.73)\end{array}$ & $\begin{array}{c}20.9 \\
(1.35)\end{array}$ & & & \\
\hline Church Bay & $\begin{array}{l}33.09 \\
(0.33)\end{array}$ & $\begin{array}{l}84.81 \\
(1.57)\end{array}$ & $\begin{array}{c}118.88 \\
(1.22)\end{array}$ & $\begin{array}{c}132.76 \\
(1.34)\end{array}$ & $\begin{array}{c}139.18 \\
(1.49)\end{array}$ & & & & $\begin{array}{c}0.8 \\
(0.02)\end{array}$ & $\begin{array}{c}6.3 \\
(0.25)\end{array}$ & $\begin{array}{c}13.0 \\
(0.26)\end{array}$ & $\begin{array}{c}16.4 \\
(0.37)\end{array}$ & $\begin{array}{c}18.2 \\
(0.42)\end{array}$ & & & \\
\hline $\begin{array}{l}\text { Carmel/ } \\
\text { Cemlyn }\end{array}$ & $\begin{array}{l}33.32 \\
(0.33)\end{array}$ & $\begin{array}{l}83.35 \\
(1.31)\end{array}$ & $\begin{array}{l}120.57 \\
(2.03)\end{array}$ & $\begin{array}{c}142.31 \\
(1.77)\end{array}$ & $\begin{array}{l}150.13 \\
(1.84)\end{array}$ & $\begin{array}{c}147.87 \\
\text { (n.a.) }\end{array}$ & $\begin{array}{c}155.53 \\
\text { (n.a.) }\end{array}$ & & $\begin{array}{c}0.8 \\
(0.02)\end{array}$ & $\begin{array}{c}6.1 \\
(0.21)\end{array}$ & $\begin{array}{c}13.4 \\
(0.50)\end{array}$ & $\begin{array}{c}19.1 \\
(0.50)\end{array}$ & $\begin{array}{c}21.4 \\
(0.55)\end{array}$ & $\begin{array}{c}23.0 \\
\text { (n.a.) }\end{array}$ & $\begin{array}{l}23.9 \\
\text { (n.a.) }\end{array}$ & \\
\hline $\begin{array}{l}\text { Mean } \\
\text { (all areas) }\end{array}$ & $\begin{array}{l}33.19 \\
(0.13)\end{array}$ & $\begin{array}{l}82.68^{*} \\
(0.55)\end{array}$ & $\begin{array}{c}114.89 * \\
(0.56)\end{array}$ & $\begin{array}{c}131.79^{*} \\
(0.72)\end{array}$ & $\begin{array}{l}141.8^{*} \\
(0.77)\end{array}$ & $\begin{array}{c}148.11 \\
(1.34)\end{array}$ & $\begin{array}{c}152.41 \\
(2.39)\end{array}$ & $\begin{array}{c}159.48 \\
\text { (n.a.) }\end{array}$ & $\begin{array}{c}0.8 \\
(0.01)\end{array}$ & $\begin{array}{l}6.0^{*} \\
(0.09)\end{array}$ & $\begin{array}{c}12.01^{*} \\
(0.13)\end{array}$ & $\begin{array}{l}16.3^{*} \\
(0.19)\end{array}$ & $\begin{array}{l}19.0^{*} \\
(0.22)\end{array}$ & $\begin{array}{c}20.9 \\
(0.40)\end{array}$ & $\begin{array}{c}22.2 \\
(0.75)\end{array}$ & $\begin{array}{l}24.5 \\
\text { (n.a.) }\end{array}$ \\
\hline
\end{tabular}



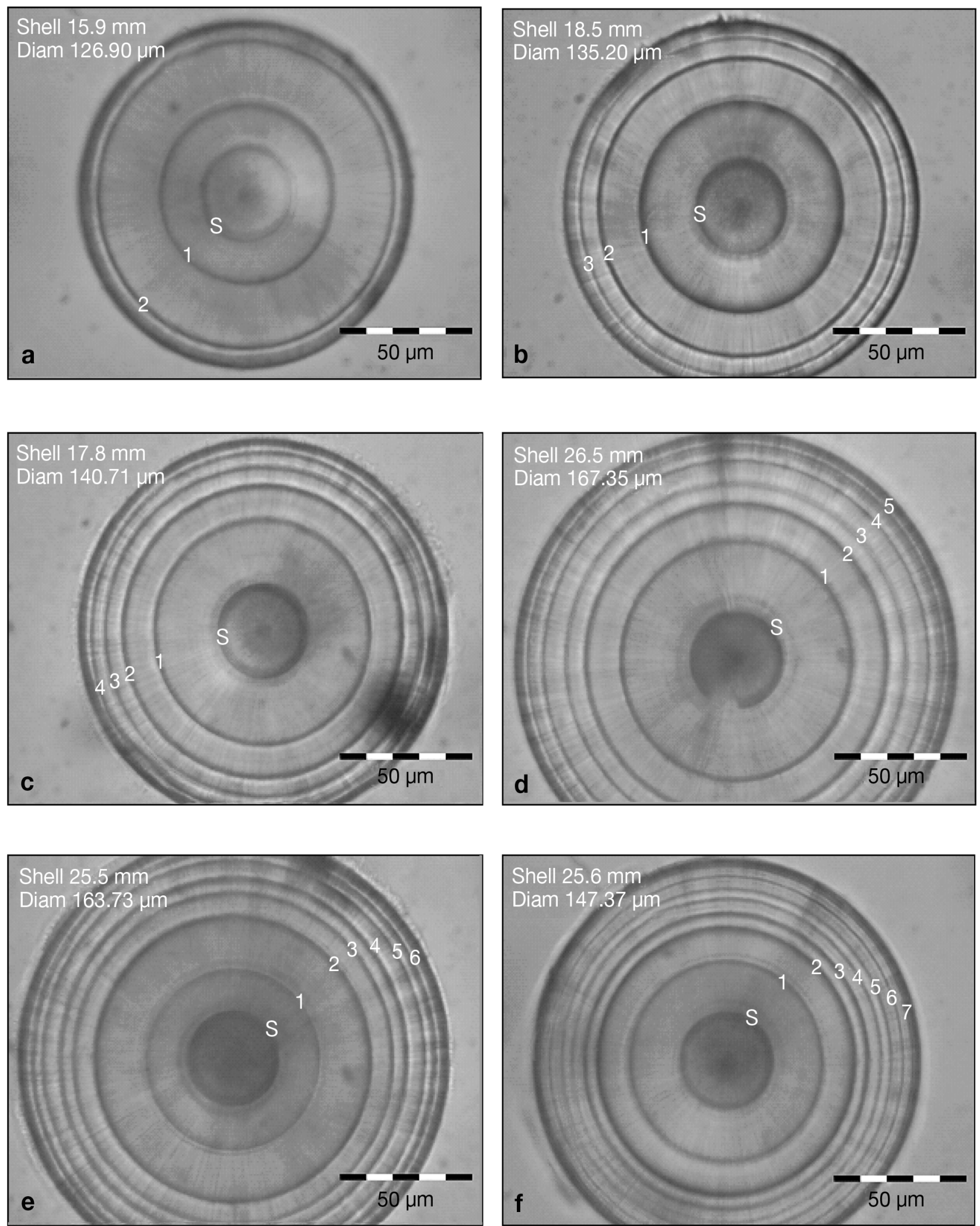

Fig. 4. Nassarius reticulatus. Photomicrographs of statoliths of adults showing positions of settlement ring (S) and annual rings (1 to 7) in statoliths. (a) 2 annual rings, (b) 3 annual rings; (c) 4 annual rings; (d) 5 annual rings; (e) 6 annual rings; (f) 7 annual rings. Shell: ShL; Diam: SDi 
observed between the diameter of the first ring in the adult statolith and the SDi of $>1$ yr old juveniles. These data strongly suggest that the clearly discernible ring (mean diameter $82.7 \pm 0.6 \mu \mathrm{m}$ ) in the adult statolith is the first annual ring.

Settlement ring diameter $(33.19 \pm 0.13 \mu \mathrm{m}$, Table 1$)$, representing the period between the embryonic and settlement phases of statolith growth, was similar amongst Nassarius reticulatus collected from the 6 different locations (Kruskal Wallis $H=0.60, \mathrm{p}=$ 0.988). However, statistically significant differences in the annual ring (Rings 1 to 4) diameters amongst whelk samples from the different locations were observed (Table 1) (Ring 1: Mood's median $\chi^{2}=$ 23.83, p < 0.001; Ring 2: Kruskal Wallis $H=74.65$, $\mathrm{p}<0.001$; Ring 3: Kruskal Wallis $H=95.76, \mathrm{p}<$ 0.001; Ring 4: Kruskal Wallis $H=41.98, \mathrm{p}<0.001$ ). Following settlement, statolith growth may be influ- enced by different environmental factors present in the different locations. $N$. reticulatus statoliths with 5 or more rings were only found at Rhosneigr, Malltraeth and between Carmel Head and Cemlyn Bay. No statistically significant difference (ANOVA $F=$ $1.15, \mathrm{p}=0.340$ ) was found in the diameter of the 5th ring $(148.11 \pm 1.34 \mu \mathrm{m})$ between the 4 areas; data for the diameter of the 6th ring were limited and so no comparisons were made. Double growth rings were occasionally observed, when the long axis of the statolith was not correctly orientated in the thermoplastic resin (Fig. 5a), although re-heating the resin and re-orientating the statolith usually overcame the problem. Tissue residues attached to the statolith (Fig. 5b), and broken or chipped statoliths arising from transfer of the statolith into the resin (Fig. 5c,d) caused some difficulty in reading the statolith growth rings.
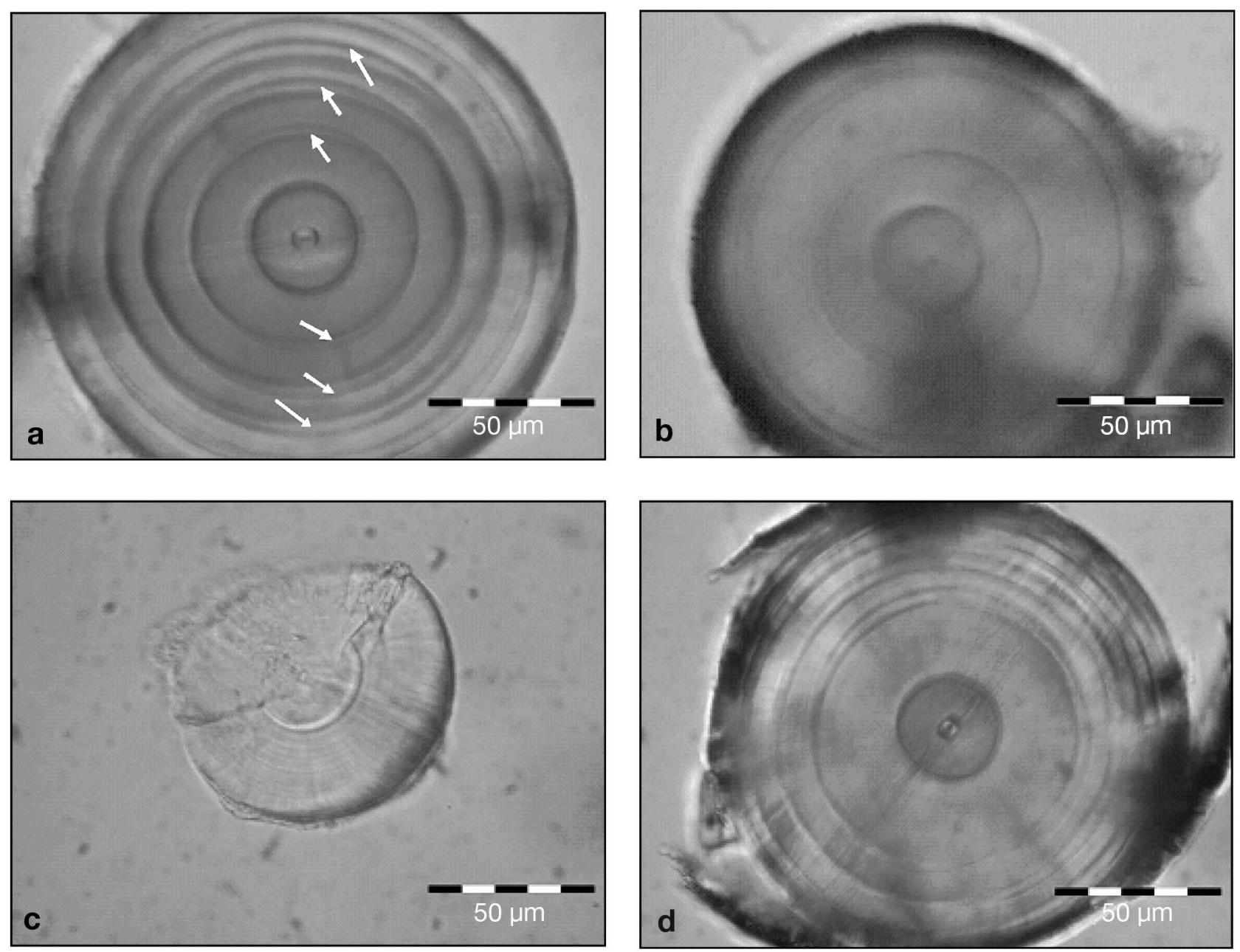

Fig. 5. Nassarius reticulatus. Photomicrographs of statoliths illustrating some difficulties encountered when preparing a statolith for study. (a) Double growth rings (arrows) occasionally appear when long axis of statolith is not correctly orientated; (b) insufficient cleaning of statolith results in adhesion of tissue residues and reduces statolith clarity; (c) rough handling of statoliths with forceps can easily break them; (d) outer rings of statolith can become damaged if insufficient care is taken during manipulation 
Seasonality in the formation of the statolith growth rings was evident in whelks from Rhosneigr lagoon (Fig. 6). Statolith circumference did not increase significantly in winter between November and late February (Mann-Whitney; $W=64.0, \mathrm{p}=0.961$ ). However in early summer (June) the growth increment was statistically significantly larger (2 sample $t$-test: $t=2.79$, $\mathrm{p}=0.012$ ) than in February, although by late summer (August) the statolith increment was similar to the June (Mann-Whitney; $W=95.0, \mathrm{p}=0.725$ ) and to the early winter (November) increment width (MannWhitney; $W=56.0, \mathrm{p}=0.054)$. These data indicate that most of the light wide ring is deposited during early summer, whereas the dark narrow ring forms between late summer and winter.

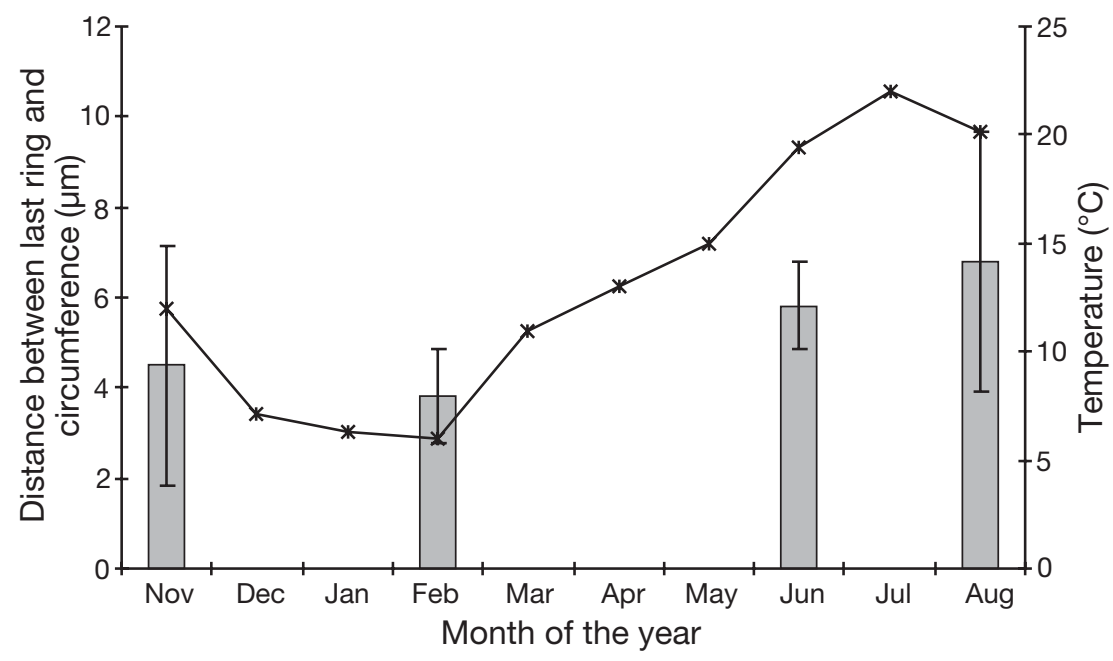

Fig. 6. Nassarius reticulatus. Comparison of seasonal change in distance $( \pm 95 \%$ CI) between last-formed growth ring and statolith circumference (bars) with measured seawater temperature $\left({ }^{\circ} \mathrm{C}\right.$ ) (curve)

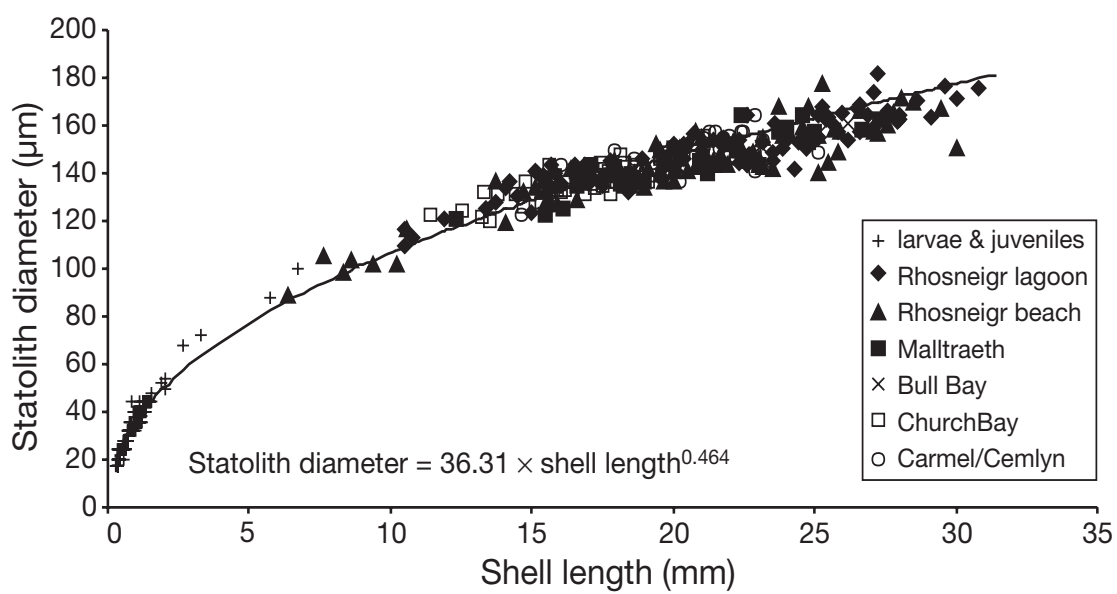

Fig. 7. Nassarius reticulatus. Relationship between SDi and ShL of larvae, juveniles and adults ( 0.3 to $31 \mathrm{~mm}$ ) collected from 6 locations around Anglesey

\section{Relationship between statolith diameter and shell length}

The relationship between SDi and ShL (range 0.3 to $31 \mathrm{~mm}$ ) of Nassarius reticulatus larvae, juveniles and adults is described by the power function $\mathrm{SDi}(\mu \mathrm{m})=$ $36.31 \times \operatorname{ShL}(\mathrm{mm})^{0.464}(F=3886.32, \mathrm{p}<0.001)$ (Fig. 7) The SDi-ShL regressions were similar amongst the 4 seasonal Rhosneigr lagoon samples (general linear model, GLM: intercept $F=2.27, \mathrm{p}=0.108$; slope $F=$ 1.99, $\mathrm{p}=0.142$ ), between the 6 Anglesey locations (GLM: intercept $F=1.24, \mathrm{p}=0.293$; slope $F=1.53, \mathrm{p}=$ 0.180 ) and between whelks of different gender (males, normal females and imposex-affected females) (GLM: intercept $F=0.54$, p $=0.583$; slope $F=0.46$, $p=0.635$ ). These analyses demonstrate that the equation is applicable to all life stages of $N$. reticulatus around Anglesey. Using the equation, whelk ShL was re-constructed from the statolith settlement and annual ring diameters (Table 1).

Comparisons, using Hotelling's $\mathrm{T}^{2}$ statistical test, of the VBG curves fitted to the length-age data, indicated that the VBG parameters $\left(\mathrm{L}_{\infty}, K\right.$ and $\left.t_{0}\right)$ (Table 2) were similar between female and male whelks and between normal and imposex affected female whelks from Rhosneigr beach, Church Bay, Bull Bay and Carmel Head to Cemlyn Bay. No comparisons were made between the whelks from Rhosneigr lagoon and Malltraeth because of the low number of males collected at these locations. The length-age data for the male, female and imposex affected female whelks in each of the 6 Anglesey samples were subsequently pooled for further analysis.

Comparisons of pairs of VBG curves for the 6 locations (Fig. 8) using Hotelling's $\mathrm{T}^{2}$ test indicated that in most cases there were statistically significant differences between the growth parameters (Table 3 ). The asymptotic maximum ShL $\left(\mathrm{L}_{\infty}\right)$ contributed most to the observed differences between the locations. Whelk shell growth in Rhosneigr lagoon, an isolated enclosed ecosystem subject to tidal emersion, was significantly different from growth in the other locations, having the highest maximum asymptotic length $(31.1 \mathrm{~mm})$ and the lowest $K(0.21)$ (Table 4). As a 
Table 2. Nassarius reticulatus. Mean $( \pm \mathrm{SE})$ growth parameters $\left(\mathrm{L}_{\infty}, K\right.$ and $\left.t_{0}\right)$ of VBG curves for female, male and imposexaffected female whelks from Rhosneigr beach, Church Bay, Bull Bay and Carmel Head to Cemlyn Bay area; n: sample size. Results of Hotelling's $\mathrm{T}^{2}$ test are indicated. n.a.: not applicable (only 1 imposex-affected female was found at Bull Bay, thus VBG curve was not constructed); similar: $\mathrm{T}^{2}<\mathrm{T}_{0}^{2}$

\begin{tabular}{|c|c|c|c|c|c|c|}
\hline Sex & $\mathrm{L}_{\infty}(\mathrm{mm})$ & $K\left(\mathrm{yr}^{-1}\right)$ & $t_{0}(\mathrm{yr})$ & $\mathrm{n}$ & Females-Males & Females-Imposex \\
\hline \multicolumn{7}{|c|}{ Rhosneigr beach } \\
\hline Females & $27.8( \pm 3.18)$ & $0.37( \pm 0.10)$ & $0.27( \pm 0.14)$ & 26 & $\mathrm{~T}^{2}=6.51$ & $\mathrm{~T}^{2}=8.16$ \\
\hline Males & $27.1( \pm 5.47)$ & $0.32( \pm 0.14)$ & $0.10( \pm 0.25)$ & 10 & $\mathrm{~T}_{0}^{2}=22.63$ & $\mathrm{~T}_{0}^{2}=24.23$ \\
\hline Imposex & $22.7( \pm 4.46)$ & $0.42( \pm 0.21)$ & $0.06( \pm 0.33)$ & 4 & similar & similar \\
\hline \multicolumn{7}{|c|}{ Church Bay } \\
\hline Females & $19.6( \pm 1.41)$ & $0.71( \pm 0.16)$ & $0.49( \pm 0.11)$ & 18 & $\mathrm{~T}^{2}=2.83$ & $\mathrm{~T}^{2}=11.68$ \\
\hline Males & $20.3( \pm 1.10)$ & $0.90( \pm 0.21)$ & $0.54( \pm 0.13)$ & 4 & $\mathrm{~T}_{0}^{2}=28.33$ & $\mathrm{~T}_{0}^{2}=24.17$ \\
\hline Imposex & $19.3( \pm 1.60)$ & $0.66( \pm 0.17)$ & $0.38( \pm 0.13)$ & 13 & similar & similar \\
\hline \multicolumn{7}{|l|}{ Bull Bay } \\
\hline Females & $25.5( \pm 3.86)$ & $0.52( \pm 0.17)$ & $0.54( \pm 0.13)$ & 8 & $\mathrm{~T}^{2}=8.92$ & n.a. \\
\hline Males & $23.1( \pm 9.66)$ & $0.70( \pm 1.00)$ & $0.40( \pm 0.65)$ & 2 & $\mathrm{~T}_{0}^{2}=94.80$ & n.a. \\
\hline Imposex & n.a. & n.a. & n.a. & 0 & similar & n.a. \\
\hline \multicolumn{7}{|c|}{ Carmel Head - Cemlyn Bay } \\
\hline Females & $27.0( \pm 3.56)$ & $0.48( \pm 0.15)$ & $0.47( \pm 0.14)$ & 13 & $\mathrm{~T}^{2}=10.08$ & $\mathrm{~T}^{2}=26.34$ \\
\hline Males & $24.3( \pm 3.27)$ & $0.52( \pm 0.20)$ & $0.48( \pm 0.20)$ & 5 & $\mathrm{~T}_{0}^{2}=33.26$ & $\mathrm{~T}_{0}^{2}=26.73$ \\
\hline Imposex & $27.8( \pm 5.33)$ & $0.39( \pm 0.18)$ & $0.34( \pm 0.19)$ & 11 & similar & similar \\
\hline
\end{tabular}

result, the lagoon whelks grow slowly and attain a large size, which results in individuals of greater age; statoliths of these whelks contained up to 7 annual rings. In contrast, whelks on the exposed Church Bay shore, NW Anglesey, had the smallest $\mathrm{L}_{\infty}(19.7 \mathrm{~mm})$ and the highest growth constant (0.69) and were younger (4 annual rings). No significant differences were apparent between the growth of whelks from Bull Bay $\left(\mathrm{L}_{\infty}=25.1 \mathrm{~mm}, K=0.52\right)$ and Carmel HeadCemlyn Bay ( $\left.\mathrm{L}_{\infty}=25.2 \mathrm{~mm}, K=0.54\right)$, located along the sheltered north coast of Anglesey. Whelk growth was similar between Malltraeth $\left(\mathrm{L}_{\infty}=25.1 \mathrm{~mm}, K=\right.$ 0.48 ) and Bull Bay ( $\left.\mathrm{L}_{\infty}=25.1 \mathrm{~mm}, K=0.52\right)$, and between Malltraeth and Carmel Head-Cemlyn Bay $\left(\mathrm{L}_{\infty}=25.2 \mu \mathrm{m}, K=0.54\right)$. Whilst Malltraeth is located on the relatively exposed SW coast of Anglesey, the whelks came from a sheltered part of the bay and this may explain why there were similarities in shell growth rates between the north- and south-facing Anglesey coastlines.

The estimated ShLs from the statolith rings of 21 marked and recaptured whelks were similar to the

Table 3. Nassarius reticulatus. Hotelling's $\mathrm{T}^{2}$ test for comparison of pairs of VBG parameters between sampling areas and Roy-Bose confidence intervals (CI) for each growth parameter. ${ }^{*}$ Statistically significant differences in shell growth between pairs of areas $\left(\mathrm{T}^{2}>\mathrm{T}_{0}{ }^{2}\right)_{i}{ }^{* *}$ parameter contributing most to differences in shell growth (CI does not include zero); n.a. non-applicable (estimation of Roy-Bose CI is not applicable when growth parameters are similar)

\begin{tabular}{|c|c|c|c|c|c|}
\hline Pairs of areas compared & $\mathrm{T}^{2}$ & $\mathrm{~T}_{0}^{2}$ & CI for $L_{\infty}$ & CI for $K$ & CI for $t_{0}$ \\
\hline Lagoon - Rhosneigr shore* & 270.67 & 17.65 & $4.61 ; 3.05^{* *}$ & $0.64 ;-0.92$ & $0.56 ;-0.99$ \\
\hline Lagoon-Malltraeth* & 1327.81 & 17.65 & $6.78 ; 5.22^{* *}$ & $0.51 ;-1.05$ & $0.21 ;-1.35$ \\
\hline Lagoon - Church Bay* & 1467.66 & 17.65 & $12.24 ; 10.62^{* *}$ & $0.33 ;-1.29$ & $0.34 ;-1.28$ \\
\hline Lagoon - Carmel/Cemlyn* & 959.10 & 17.67 & $6.82 ; 5.06^{* *}$ & $0.55 ;-1.21$ & $0.36 ;-1.40$ \\
\hline Lagoon - Bull Bay* & 390.46 & 17.71 & $7.29 ; 4.73^{* *}$ & $0.97 ;-1.59$ & $0.80 ;-1.76$ \\
\hline Malltraeth - Rhosneigr* & 211.80 & 21.86 & $-1.13_{i}-3.22^{* *}$ & $1.18 ;-0.92$ & $1.40 ;-0.70$ \\
\hline Malltraeth - Church Bay* & 64.64 & 21.89 & $6.50 ; 4.36^{* *}$ & $0.87 ;-1.29$ & $1.18 ;-0.98$ \\
\hline Malltraeth - Carmel/Cemlyn & 4.22 & 21.96 & n.a. & n.a. & n.a. \\
\hline Malltraeth - Bull Bay & 8.95 & 22.19 & n.a. & n.a. & n.a. \\
\hline Rhosneigr shore-Church Bay* & 309.32 & 21.89 & $8.68 ; 6.53^{* *}$ & $0.74 ;-1.42$ & $0.83 ;-1.33$ \\
\hline Rhosneigr shore-Carmel/Cemlyn* & 140.55 & 21.96 & $3.25 ; 0.97^{* *}$ & $0.95 ;-1.33$ & $0.84 ;-1.44$ \\
\hline Rhosneigr shore-Bull Bay* & 53.01 & 22.19 & $3.73 ; 0.63^{* *}$ & $1.38 ;-1.72$ & $1.29 ;-1.81$ \\
\hline Church Bay-Carmel/Cemlyn* & 94.36 & 22.00 & $-4.32 ;-6.66^{* *}$ & $1.32 ;-1.02$ & $1.12 ;-1.22$ \\
\hline Church Bay-Bull Bay* & 43.67 & 22.27 & $-3.85 ;-6.99^{* *}$ & $1.74 ;-1.40$ & $1.56 ;-1.58$ \\
\hline Carmel/Cemlyn-Bull Bay & 2.47 & 22.45 & n.a. & n.a. & n.a. \\
\hline
\end{tabular}



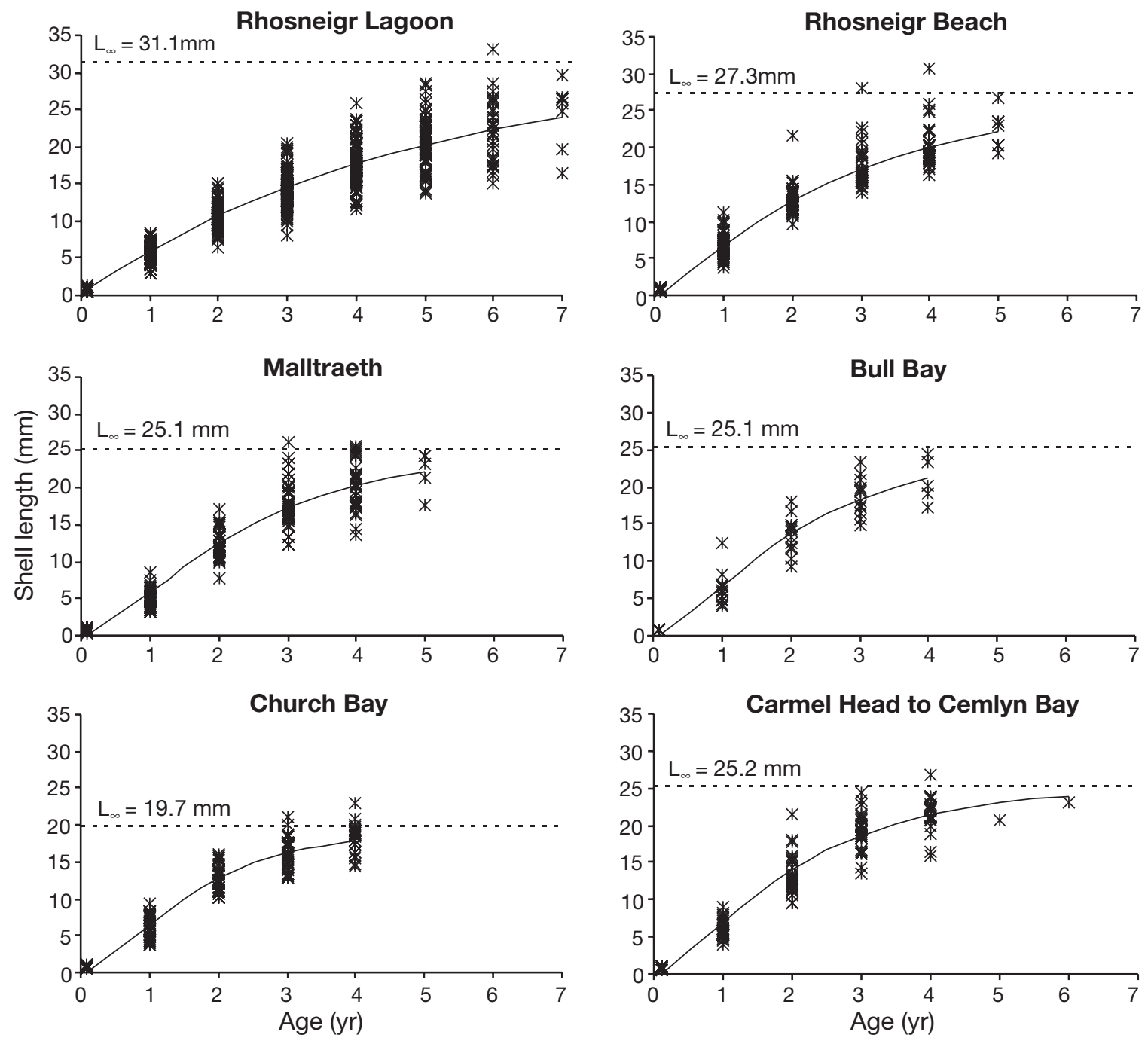

Fig. 8. Nassarius reticulatus. VBG curves (solid curves) for whelks from 6 locations around Anglesey. ShL estimated from statolith rings; estimated asymptotic length $\left(\mathrm{L}_{\infty}\right)$ (dashed line) is noted on each graph

actual final lengths measured following recapture (2-sample $t$-test: $t=-0.82, \mathrm{p}=0.414)$. These observations indicate that estimates of ShL from the statolith rings reliably reflect shell size in the natural environment. A 1-way ANOVA comparison indicated statistically significant differences $(F=30.94, \mathrm{p}<0.001)$ in the SDis of whelks displaying the 4 categories of shell lip condition (CL). CL1 and CL4 whelks had the smallest and largest SDis, respectively $(131.1 \pm 3.89 \mu \mathrm{m}$ and $156.41 \pm 1.78 \mu \mathrm{m})$, whilst CL2 and CL3 whelks had intermediate SDis $(135.81 \pm 1.32 \mu \mathrm{m}$ and $145.70 \pm$ $0.83 \mu \mathrm{m}$, respectively). The percentage of whelks characterised by CL1 to CL4 was calculated for the 3, 4 and $5 \mathrm{yr}$ age classes (Fig. 9). In the $3 \mathrm{yr}$ age class, $68.4 \%$ of the whelks displayed a CL 3 stage and $7.9 \%$ a CL 4 stage, whereas in the 4 yr age class, $67 \%$ of the whelks had CL 3 lips and $11.3 \%$ had CL 4 lips. In the 5 yr age class the percentage of whelks with CL 4 lips increased to $38.5 \%$, while $53.9 \%$ had CL 3 lips. These data demonstrate that shell lip thickening and the formation of teeth on the inner lip are associated with the older age classes of Nassarius reticulatus. However, since a high percentage of whelks from all the age classes displayed a CL 3 lip stage, shell lip thickness can only be used as an indicator of mature age and not as a method for determining empirically the age of $N$. reticulatus.

\section{DISCUSSION}

The period that Nassarius reticulatus statoliths were clearly visible through the larval shell (up to $5 \mathrm{wk}$ after hatching) is significantly longer than that recorded for Polinices pulchellus (14 di Kingsley-Smith et al. 2005). 
Table 4. Nassarius reticulatus. Mean $( \pm \mathrm{SE})$ growth parameters $\left(\mathrm{L}_{\infty}, K\right.$ and $\left.t_{0}\right)$ of VBG curves describing patterns of shell growth of whelks from 6 different locations

\begin{tabular}{|lcccrrr|}
\hline Location & $\mathrm{L}_{\infty}(\mathrm{mm})$ & $K\left(\mathrm{yr}^{-1}\right)$ & $t_{0}(\mathrm{yr})$ & $\begin{array}{c}\text { Sample } \\
\text { size }\end{array}$ \\
\hline Rhosneigr lagoon & $31.1( \pm 2.63)$ & $0.21( \pm 0.03)$ & $-0.02( \pm 0.09)$ & 106 \\
Malltraeth & $25.1( \pm 1.95)$ & $0.48( \pm 0.10)$ & $0.55( \pm 0.07)$ & 40 \\
Rhosneigr beach & $27.3( \pm 4.85)$ & $0.35( \pm 0.13)$ & $0.20( \pm 0.14)$ & 40 \\
Bull Bay & $25.1( \pm 2.35)$ & $0.52( \pm 0.10)$ & $0.46( \pm 0.07)$ & 12 \\
Church Bay & $19.7( \pm 1.89)$ & $0.69( \pm 0.17)$ & $0.45( \pm 0.10)$ & 36 \\
Carmel/Cemlyn & $25.2( \pm 1.82)$ & $0.54( \pm 0.09)$ & $0.50( \pm 0.08)$ & 29 \\
\hline
\end{tabular}

hatched. The present study has demonstrated unequivocally that the first statolith ring in $N$. reticulatus is formed at settlement and not during hatching. There is, however, evidence to indicate in gastropod species that have direct larval development within egg capsules and hatch as juveniles, e.g. Buccinum undatum and Nucella lapillus, that the first ring forms at hatching (Karageorgopoulos 1997, Saurel 2002).

Barroso et al. (2005b) and Richardson et al. (2005a) suggested that the forma-

In $N$. reticulatus the statolith nucleus was $5 \mu \mathrm{m}$ in diameter and in the developing embryos enclosed in their egg capsules the SDi was $12.5 \mu \mathrm{m}$; upon hatching the diameter increased to $17.5 \mu \mathrm{m}$. Barroso et al. (2005b) similarly noted that the diameter of the larval statolith of $N$. reticulatus at hatching was $16 \mu \mathrm{m}$, and 6 d later was $20 \mu \mathrm{m}$ in non-fed larvae. In the current study the first ring $(34.0 \mu \mathrm{m})$ formed in the statolith during larval settlement, and had a similar diameter to the first ring $(33.2 \mu \mathrm{m})$ in the adult statolith, possibly reflecting the shift from a pelagic to a benthic habitat. The statolith microstructure of the squid Moroteuthis ingens consists of 2 distinct zones, an inner opaque and an outer translucent zone, which reflected a habitat shift from the pelagic to the demersal phase of growth (Jackson 1993).

Zacherl et al. (2003) suggested, on the basis that the SDi of Concholepas concholepas larvae at hatching was similar to the diameter of the first prominent ring in the juvenile statolith, that the ring was formed during the transition from egg capsule to planktonic larval life. Richardson et al. (2005a) and Barroso et al. (2005b) have demonstrated that the SDis of Polinices pulchellus and Nassarius reticulatus, respectively, were smaller during planktonic life (pre-settlement) than the diameter of the 1 st ring in the adult statolith and concluded that the formation of the first statolith ring occurred during settlement, and not when the larvae

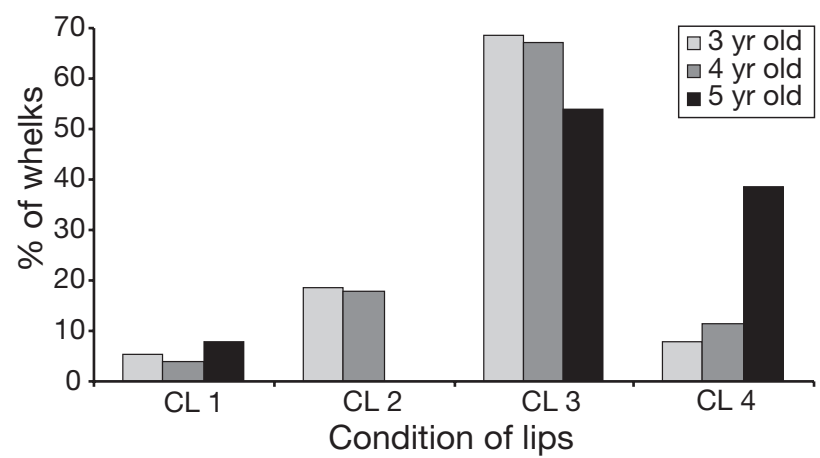

Fig. 9. Nassarius reticulatus. Percentage of whelks of 3 different age classes ( 3 to $5 \mathrm{yr}$ ) with lip conditions CL 1 to CL 4 tion of rings in Nassarius reticulatus and Polinices pulchellus statoliths is probably annual. Using modal size (age) classes in length-frequency data, the ShLs of 1 and 2 yr old P. pulchellus (Richardson et al. 2005a) and N. reticulatus (Barroso et al. 2005b) were shown to be similar to the estimated ShLs from the 1st and 2nd statolith rings. Richardson et al. (2005b) concluded that the statolith rings in Neptunea antiqua were deposited annually, since the number of rings closely agreed with the number of seasonal $\mathrm{Mg}$ : Ca ratio cycles in the shells. Statolith ring analysis of laboratory-reared juvenile $N$. reticulatus of known age in the present study validated an annual ring periodicity. The SDi of $>1 \mathrm{yr}$ old juveniles was similar to the diameter of the first post-settlement ring in adults, whereas juveniles $<1 \mathrm{yr}$ old had significantly smaller SDis. The formation of a statolith ring in $N$. reticulatus coincided with a period of slow growth between late summer and winter, possibly due to reproduction initially (E. Chatzinikolaou unpubl. data) and in response to cooler seawater temperatures later. When temperatures increased in spring from $10.9^{\circ} \mathrm{C}$ in March to $19.4^{\circ} \mathrm{C}$ in June, incremental growth of the statoliths accelerated until the early summer. Radtke et al. (1985) noted that the wider hyaline areas (wide light rings) in oyster toadfish Opsanus tau otoliths corresponded to periods of fast growth during the summer, whilst the thinner opaque areas (dark rings) were related to periods of slow growth during the winter.

No differences in the relationship between ShL and SDi were found amongst Nassarius reticulatus of different gender or between whelks from the 6 different locations around Anglesey. Arkhipkin \& Mikheev (1992) demonstrated that the relationship between statolith length and mantle length was similar for male and female Sthenoteuthis pteropus. Radtke et al. (1985) noted there was a similar relationship between body length and otolith diameter in both sexes of the oyster toadfish Opsanus tau. Lipinski (1980) did not find any gender or geographical differences in the relationship between statolith size and body size in the squid Illex illecebrosus. In contrast, Barroso et al. 
(2005b) found (using a rather dissimilar size range of $N$. reticulatus) that the relationship between SDi and ShL was significantly different amongst 3 populations of whelks from the Ria de Aveiro (Portugal). Once a relationship between SDi and ShL has been established, shell growth can be reconstructed from the statolith ring diameters. This method has been used successfully to reconstruct growth of the gastropods Polinices pulchellus (Richardson et al. 2005a) and $N$. reticulatus (Barroso et al. 2005b). Growth of the cephalopod Alloteuthis subulata has been backcalculated using the relationship between dorsal mantle length and statolith dimensions (Lipinski 1986), and in Sepia hierredda using the relationship between mantle length and minimum radius of the statolith lateral dome (Raya et al. 1994).

The back-calculation of age-specific growth rates can provide information about the growth patterns and life history strategies of an organism during its lifetime in different ecosystems. For example, differences in the size of the settlement ring in gastropods from different areas can reveal variations in the length of their larval planktonic life and the timing of larval release into the plankton. Richardson et al. (2005a) suggested that a large settlement ring in Polinices pulchellus might result from longer residence time in the plankton, because planktonic development would be slower and take longer at lower seawater temperatures following recruitment in the spring. In this study no evidence was found for geographical variations in the size of the settlement ring in Nassarius reticulatus from around Anglesey, thus suggesting that the larvae spend a similar period of time in the plankton before settlement. Significant differences in the diameters of the 1st, 2nd, 3rd and 4th annual statolith rings were, however, evident amongst whelks collected from the 6 locations suggesting that wave exposure, food availability, or genetic factors might be responsible for promoting growth in the different habitats. No statistically significant differences between the growth rates of female and male $N$. reticulatus were observed. Similar growth rates between males and females have been reported for other gastropod species, such as Ilyanassa obsoleta (Curtis 1995) and Concholepas concholepas (Rabi \& Maravi 1991). In the present study imposexaffected female $N$. reticulatus had similar growth to normal females; however, tributyltin (TBT) pollution has been shown to affect growth rates of Stramonita haemastoma and Hexaplex trunculus (Rilov et al. 2000).

Significant variations were observed in the growth patterns of Nassarius reticulatus from different areas around Anglesey. Whelks had a slow growth rate in the sheltered Rhosneigr lagoon but reached a larger size over a longer time period, whereas whelks from the exposed Church Bay had the lowest maximum asymptotic length and the highest $K$. Differences in shore exposure and predation pressure amongst whelks from the different locations might account for the observed differences in shell sizes and growth rates. In enclosed lagoons, characterised by the lack of wave exposure and greater populations of predatory crabs, thickening of the shell is promoted instead of an increase in ShL (Wellington \& Kuris 1983). Slowergrowing $N$. reticulatus in the Rhosneigr lagoon presumably invested more energy into shell thickening for protection against predators. Production of a thick shell is energetically costly (Palmer 1992) and can restrict the maximum rate of body growth (Trussell \& Smith 2000). Slow-growing adult Bembicium vittatum displayed thicker shells than fast-growing adults (Parsons 1997). In the presence of water containing the chemical signatures of predatory crustaceans, the shells of Littorina obtusata grew more slowly and became thickened (Trussell \& Smith 2000). Individuals of Littorina sp. with thickened shells are less preferred by shore crabs and can withstand significantly more force than thinner-shelled conspecifics (Boulding \& Van Alstyne 1993). Although $N$. reticulatus from the sheltered locations around Anglesey had lower growth rates $(K)$, this resulted in whelks of larger asymptotic length $\left(\mathrm{L}_{\infty}\right)$ and presumably offered better protection against predation (see Parsons 1997). Relative shell strength increases roughly with the $1 / 3$ power of $\mathrm{ShL}$, thus longer gastropod shells are stronger than short ones (Tokeshi et al. 2000) because long shells require more energy to break (Juanes 1992).

Shell lip thickness and teeth-like sculpturing on the inner lip have been directly linked to maturity in gastropods. The inner lip of the shell of Nassarius reticulatus thickens after maturity and forms a set of ridges with 6 to 9 longitudinally elongated teeth (Fretter \& Graham 1984). In the present study, N. reticulatus with thin shell lips had smaller statoliths than those with thick shell lips and teeth. Mixed age classes were present in each of the shell lip condition categories, thus shell thickness and formation of teeth can only be used as a rough indicator that the whelks are older and more mature. Shell lip thickness can be severely affected as a result of damage due to predation or erosion. Statoliths are completely protected and isolated from the external environment, and information concerning the past history of the organisms cannot be modified.

The current research has validated an annual periodicity of growth ring formation in the statoliths of Nassarius reticulatus and has demonstrated a novel approach of using the growth rings for interpreting the past growth history of these gastropods. This groundbreaking study has highlighted the potential use of a 
technique which could now be used routinely for investigating growth in a variety of gastropod species from a range of habitats. The information obtained will further our understanding of the effects of environmental factors on gastropod shell growth.

Acknowledgements. The authors are grateful to G. P. Jones and B. Roberts for their assistance in collecting the Nassarius reticulatus.

\section{LITERATURE CITED}

Appeldoorn RS (1988) Age determination, growth, mortality and age of first reproduction in adult queen conch, Strombus gigas L., off Puerto-Rico. Fish Res 6:363-378

Arkhipkin AI, Bizikov VA (1997) Statolith shape and microstructure in studies of systematics, age and growth in planktonic paralarvae of gonatid squids (Cephalopoda: Oegopsida) from the western Bering Sea. J Plankton Res 19:1993-2030

Arkhipkin AI, Mikheev A (1992) Age and growth of the squid Sthenoteuthis pteropus (Oegopsida: Ommastrephidae) from the Central-East Atlantic. J Exp Mar Biol Ecol 163: 261-276

Ballantine WJ (1961) A biologically-defined exposure scale for the comparative description of rocky shores. Field Stud 1:1-19

Barroso CM, Moreira MH, Richardson CA (2005a) Age and growth of Nassarius reticulatus in the Ria de Aveiro, north-west Portugal. J Mar Biol Assoc UK 85:151-156

Barroso CM, Nunes M, Richardson CA, Moreira MH (2005b) The gastropod statolith: a tool for determining the age of Nassarius reticulatus. Mar Biol 146:1139-1144

Bell JL (1984) Statoliths as age indicators in gastropod larvae: application to measurement of field growth rates. Pac Sci 38:357

Bernard DR (1981) Multivariate analysis as a means of comparing growth in fish. Can J Fish Aquat Sci 38:233-236

Boulding EG, Van Alstyne KL (1993) Mechanisms of differential survival and growth in two species of Littorina on wave-exposed and on protected shores. J Exp Mar Biol Ecol 169:139-166

Bretos M (1980) Age determination in the keyhole limpet Fissurella crassa Lamarck (Archaeogastropoda: Fissurellidae), based on shell growth rings. Biol Bull (Woods Hole) 159:606-612

Coombs VA (1973) A quantitative system of age analysis for the dog-whelk, Nucella lapillus. J Zool 171:437-448

Crothers JH (1985) Dogwhelks: an introduction to biology of Nucella lapillus (L.). Field Stud 6:291-360

Curtis LA (1995) Growth, trematode parasitism, and longevity of a long-lived marine gastropod (Ilyanassa obsoleta). J Mar Biol Assoc UK 75:913-925

Dorsett DA (1986) Brains to cells: the neuroanatomy of selected gastropod species. In: Willow DAO (ed) The Mollusca. Neurobiology \& behaviour, part II. Academic Press, New York, p 101-187

Ekaratne SUK, Crisp DJ (1984) Seasonal growth studies of intertidal gastropods from shell micro-growth band measurements, including a comparison with alternative methods. J Mar Biol Assoc UK 64:183-210

Fretter V, Graham A (1984) The prosobranch mollusks of Britain and Denmark. Part 8. Neogastropoda. J Molluscan Stud Suppl 15:435-556

Grana-Raffucci FA, Appeldoorn RS (1997) Age determination of larval strombid gastrpods by means of growth increment counts in statoliths. Fish Bull Suppl 95:857-862

Jackson GD (1993) Growth zones within the statolith microstructure of the deepwater squid Moroteuthis ingens (Cephalopoda: Onychoteuthidae): evidence for a habitat shift? Can J Fish Aquat Sci 50:2366-2374

Jackson GD (2004) Advances in defining the life histories of myopsid squid. Mar Freshw Res 55:357-365

Juanes F (1992) Why do decapod crustaceans prefer smallsized molluscan prey? Mar Ecol Prog Ser 87:239-249

Karageorgopoulos P (1997) Demographic analysis, age determination and fisheries of three stocks of the common whelk, Buccinum undatum (Linnaeus, 1758) from around Anglesey, North Wales. MSc thesis, School of Ocean Sciences, University of Wales, Bangor

Kingsley-Smith PR, Richardson CA, Seed R (2005) Growth and development of the veliger larvae and juveniles of Polinices pulchellus (Gastropoda: Naticidae). J Mar Biol Assoc UK 85:171-174

Lipinski MR (1980) Statoliths as a possible tool for squid age determination. Bull Acad Pol Sci CL II Sér Sci Biol 28: 569-582

Lipinski MR (1986) Methods for the validation of squid age from statoliths. J Mar Biol Assoc UK 66:505-526

Palmer AR (1992) Calcification in marine molluscs: How costly is it? Proc Natl Acad Sci USA 89:1379-1382

Parsons KE (1997) Contrasting patterns of heritable geographic variation in shell morphology and growth potential in the marine gatsropod Bembicium vittatum: evidence from field experiments. Evolution 51:784-796

Rabi M, Maravi C (1991) Growth curves and specific growth rate of Concholepas concholepas (Bruguiere, 1789) (Gastropoda: Muricidae) in culture experiments. Sci Mar 61: 49-53

Radtke RL (1983) Chemical and structural characteristics of statoliths from the short-finned squid Illex illecebrosus. Mar Biol 76:47-54

Radtke RL, Fine ML, Bell JL (1985) Somatic and otolith growth in the oyster toadfish (Opsanus tau L.). J Exp Mar Biol Ecol 90:259-275

Raya CP, Fernandez-Nunez M, Balguerias E, HernandezGonzalez CL (1994) Progress towards ageing cuttlefish Sepia hierredda from the northwestern African coast using statoliths. Mar Ecol Prog Ser 114:139-147

Richardson CA (2001) Molluscs as archives of environmental change. Oceanogr Mar Biol Annu Rev 39:103-164

Richardson CA, Kingsley-Smith PR, Seed R, Chatzinikolaou E (2005a) Age and growth of the naticid gastropod Polinices pulchellus (Gastropoda: Naticidae) based on length frequency analysis and statolith growth rings. Mar Biol 148: 319-326

Richardson CA, Saurel C, Barroso CM, Thain J (2005b) Evaluation of the age of the red whelk Neptunea antiqua using statoliths, opercula and element ratios in the shell. J Exp Mar Biol Ecol 325:55-64

Rilov G, Gasith A, Evans SM, Benayahu Y (2000) Unregulated use of TBT-based antifouling paints in Israel (eastern Mediterranean): high contamination and imposex levels in two species of marine gastropods. Mar Ecol Prog Ser 192: $229-238$

Saurel C (2002) An investigation into the use of statoliths for determining the age and growth rate of dog whelks $\mathrm{Nu}$ cella lapillus (L.) in North Wales. MSc thesis, University of Wales, Bangor

Shepherd SA, Avalos-Borja M, Quintanilla MO (1995) Toward a chronology of Haliotis fulgens, with a review of abalone shell microstructure. Mar Freshw Res 46:607-615 
Stoner AW, Sandt VJ (1992) Population structure, seasonal movements and feeding of the queen conch, Strombus gigas, in deep-water habitats of the Bahamas. Bull Mar Sci 51:287-300

Stroben E, Oehlmann J, Fioroni P (1992) The morphological expression of imposex in Hinia reticulata (Gastropoda: Buccinidae): a potential indicator of tributyltin pollution. Mar Biol 113:625-636

Tallmark B (1980) Population dynamics of Nassarius reticulatus (Gastropods, Prosobranchia) in Gullmar Fjord, Sweden. Mar Ecol Prog Ser 3:51-62

Tokeshi M, Ota N, Kawai T (2000) A comparative study of morphometry in shell-bearing molluscs. J Zool 251:31-38

Trussell GC, Smith DL (2000) Induced defenses in response to

Editorial responsibility: Otto Kinne (Editor-in-Chief),

Oldendorf/Luhe, Germany an invading crab predator: an explanation of historical and geographic phenotypic change. Proc Natl Acad Sci USA 97:2123-2127

Wellington GM, Kuris AM (1983) Growth and shell variation in the tropical eastern Pacific intertidal gastropod genus Purpura: ecological and evolutionary implications. Biol Bull (Woods Hole) 164:518-535

Williamson P, Kendall MA (1981) Population age structure and growth of the trochid Monodonta lineata determined from shell rings. J Mar Biol Assoc UK 61:1011-1026

Zacherl DC, Manriquez PH, Paradis G, Day RW, Castilla JC, Warner RR, Lea DW, Gaines SD (2003) Trace elemental fingerprinting of gastropod statoliths to study larval dispersal trajectories. Mar Ecol Prog Ser 248:297-303

Submitted: July 28, 2006; Accepted: December 21, 2006

Proofs received from author(s): June 13, 2007 